\title{
Clara cell protein 16 release from the nasal mucosa in allergic rhinitis, chronic rhinosinusitis, and exposure to air pollutants
}

\author{
Aleksandar Perić ${ }^{1}$, Cveta Špadijer Mirković ${ }^{1}$, and Danilo Vojvodić ${ }^{2}$ \\ Department of Otorhinolaryngology, Institute for Medical Research, Division of Clinical \& Experimental \\ Immunology², Military Medical Academy School of Medicine, Belgrade, Serbia
}

[Received in December 2017; Similarity Check in December 2017; Accepted in September 2018]

Clara cell protein $16(\mathrm{CC} 16)$ is a small protein mainly produced by non-ciliated Clara cells in the respiratory epithelium. It has an anti-inflammatory role in chronic upper and lower airway eosinophilic inflammations. Decreased levels of CC16 are found in the nasal secretions and plasma of patients with chronic eosinophilic inflammatory disorders, such as asthma, allergic rhinitis, and chronic rhinosinusitis with or without nasal polyps, as well as in people exposed to high levels of air pollutants. Intranasal corticosteroid administration suppresses chronic inflammation of the nasal mucosa driven by eosinophils and stimulates local CC16 production. CC16 can be a reliable biomarker of the beneficial effects of perennial allergic rhinitis and chronic rhinosinusitis therapy and of the functional recovery of the nasal mucosa after treatment with topical glucocorticoids.

KEY WORDS: glucocorticoids; inflammatory mediators; nasal polyps

\section{ALLERGIC RHINITIS AND \\ CHRONIC RHINOSINUSITIS: DEFINITION, CLASSIFICATION, AND PATHOPHYSIOLOGY}

\section{Allergic rhinitis}

Allergic rhinitis (AR) is a non-infectious chronic inflammatory disease of the nasal mucosa mediated by immunoglobulin $\mathrm{E}(\mathrm{IgE})$ in response to allergen exposure. What plays an essential role in the development of AR is the imbalance between T helper 1 and T helper 2 (Th1/Th2) cells, where the inflammation-mediating Th2 cells prevail (1). The disease most often presents itself as a noninfectious upper airway inflammation and affects between 10 and $30 \%$ of people in Western Europe and North America.

According to clinical characteristics, AR can be divided into seasonal and perennial. In patients with the seasonal allergic rhinitis (SAR), inflammation is most often triggered by the pollen of specific seasonal plants; hence the name "hay fever". Which pollen shall trigger SAR will vary between individuals and regions, but it is generally caused by the tiny, barely visible pollens of wind-pollinated plants (2). Perennial AR (PAR), in turn lasts throughout the year and is a reaction to perennial allergens: house dust mites,

Correspondence to: Aleksandar Perić, $\mathrm{MD}, \mathrm{PhD}$, Department of Otorhinolaryngology, Military Medical Academy School of Medicine, Crnotravska 17, 11000 Belgrade, Serbia; E-mail: alexneta@orion.rs fungi, animal dander, and such. It starts with the action of antigen-specific Th2 lymphocytes that secrete Th2 cytokines, especially interleukin-4 (IL-4), IL-5, and IL-13, and is characterised by specific IgE in the early stage of allergic inflammation and secretory products in the late stage (3). These products, eosinophil cationic protein (ECP), major basic protein (MBP), and eosinophil peroxidases (EPOs) in particular, damage lamina propria (subepithelium) and cause localised oedema, resulting in the structural changes of the nasal mucosa (3). They seem to stimulate the so-called C-fibres and eventually nasal hyperreactivity, which is so characteristic for PAR. Henriquez et al. (4) clearly demonstrated higher permeability of cell membranes of cultured nasal epithelial cells following exposure to house dust mite antigens. Wise et al. (5) reported structural changes in intercellular junction proteins after prolonged exposure of nasal epithelial cells to Th2 cytokines (IL-4 and IL-13), resulting in their increased permeability. These structural changes could explain some of the clinical signs of Th2-mediated sinonasal disease, such as oedema, nasal hypersecretion, and non-specific hyperreactivity (5).

According to the symptom frequency, AR can also be classified as intermittent and persistent. In intermittent AR symptoms occur less than four days a week over less than four weeks in a row. Persistent AR symptoms occur more than four days a week over more than four weeks.

According to the severity of clinical manifestations, AR can be divided into mild and moderate-to-severe. The symptoms are considered mild if they do not affect sleep or daily activities, including work or school. Moderate to 
severe symptoms, however, disturb sleep, and affect daily activities (1).

\section{Chronic rhinosinusitis}

Chronic rhinosinusitis (CRS) is a very common inflammatory disease of the nasal and paranasal sinus mucosa with a duration of more than 12 weeks that can severely affect the quality of life. The most severe form is CRS with nasal polyps NPs (CRSwNP), characterised by frequent polyp recurrence despite medical and surgical therapy. Its exact aetiology and pathophysiology, however, remain unclear. The main characteristic of CRS is prolonged inflammation of the nasal and paranasal sinus mucosa. The inflammatory reaction is very important in the elimination of microbes, allergens, air pollutants, and other agents. However, it can also be harmful to the host, if the mechanisms regulating inflammatory mediator production are disturbed. A dysfunctional production of antiinflammatory mediators can lead to hyperinflammatory states and therefore exacerbate the chronic condition of the mucosa.

The pathogenesis of hypereosinophilia of the nasal mucosa in patients with PAR, CRSwNPs, and non-allergic rhinitis with eosinophilia syndrome (NARES) has been investigated poorly. A few studies showed an increased transendothelial migration of eosinophils, guided by chemokines in all chronic sinonasal eosinophilic inflammatory disorders $(6,7)$.

Eosinophil chemokines can be selective and nonselective. Non-selective chemokines include regulated on activation normal $\mathrm{T}$ cell expressed and secreted (RANTES), macrophage inflammatory protein-1 alpha (MIP-1 $\alpha$ ), MIP$1 \beta$, and monocyte chemoattractant proteins 1,3 , and 4 (MCP-1, MCP-3, and MCP-4), as they attract not only eosinophils, but also monocytes, macrophages, and lymphocytes $(7,8)$. Selective chemokines, eotaxin-1, -2, and -3 attract only eosinophils via a specific CC chemokine receptor 3 (CCR3) (7).

\section{ORIGIN AND FUNCTION OF THE CLARA CELL PROTEIN 16}

The pseudostratified respiratory epithelium acts as the first line of defence against allergens, microbes, and air pollutant particles. To that effect, respiratory epithelium cells produce cytokines, chemokines, and other mediators of the immune system. Clara cells, also known as "club cells", are non-ciliated secretory cells, situated among the ciliated cells of the columnar respiratory epithelium of the nasal cavity, paranasal sinuses, and tracheobronchial and bronchoalveolar parts of the airway. They modulate immune responses by secreting anti-inflammatory proteins (9). One of these anti-inflammatory and antioxidant proteins is the Clara cell protein 16 (CC16) with the molecular mass of only $16 \mathrm{kDa}$, also known as uteroglobin, secretoglobin-1a1, and club cell secretory protein (9). CC16 is secreted in the lining of the bronchoalveolar and nasal cavity and paranasal sinuses. It suppresses the activity of pro-inflammatory enzymes phospholipase A2 (PLA2) and transglutaminase, very important in arachidonic acid production and release during eosinophilic inflammation of the respiratory mucosa $(9-11)$.

\section{THE ROLE OF CC16 IN AR AND CRS}

Johansson et al. (9) reported a negative correlation between the $\mathrm{CC} 16$ levels in nasal secretions and the severity of rhinitis symptoms in patients with SAR. In children with birch pollen-induced AR its levels in nasal fluid were reported lower than in subjects with healthy nasal mucosa, both before and during the pollen season (10). A similar finding of lower CC16 in serum and nasal discharge was reported in children with AR (11). In patients with PAR, nasal fluid $\mathrm{CC} 16$ positively correlated with nasal nitric oxide (NO) levels, and the two negatively correlated with mast cell counts in the nasal mucosal lining, which points to the protective role of both $\mathrm{CC} 16$ and $\mathrm{NO}$, as they inhibit cell chemotaxis in chronically inflamed nasal mucosa (12). In an experimental investigation, Roth et al. (13) demonstrated that long-term exposure to perennial allergens caused most Clara cells to transform into large secretory goblet cells, which resulted in lower $\mathrm{CC} 16$ and higher mucus production in the bronchoalveolar mucosa. Studies with patients with PAR and CRSwNP demonstrated similar inhibition of CC16 nasal mucosa production by eosinophil inflammation (11, 14). One study (15) showed significantly lower mean CC16 levels in the nasal secretions of patients with SAR, PAR, and (allergic and non-allergic) than controls whose nasal mucosa was not inflamed (15). In yet another study (16) CC16 immunoexpression in the mucosa of CRS patients with and without nasal polyps was significantly lower than in controls with healthy nasal mucosa. CC16 in plasma also negatively correlated with preoperative computed tomography (CT) scores and postoperative nasal endoscopy and symptom scores. Strong pro-inflammatory cytokines TNF- $\alpha$, IL- $1 \beta$ and IL-4 inhibited, whereas anti-inflammatory cytokines IFN- $\gamma$ and IL-10 promoted CC16 production in the nasal mucosa (16).

Different cytokines and chemokines regulate $\mathrm{CC} 16$ expression in the nasal mucosa by modulating mRNA tissue expression $(16,17)$. The relationship between local mucosal production of eosinophilic chemokines and CC16 is very important for the development and further control of chronic inflammation. Previous investigations have demonstrated that eotaxins induce stronger transendothelial migration of eosinophils than of other eosinophilic chemokines (17-21). Shin et al. (22) reported inverse correlation between CC16 and eotaxin-2 in the nasal secretion of PAR subjects. Eosinophils are attracted to the site of inflammation mainly by eotaxins and in smaller part by other, non-selective 
eosinophil chemokines. The attracted and activated eosinophils, in turn, attract new eosinophils by synthesising more eotaxins. Activated eosinophils release high amounts of ECP and other toxic enzymes that affect nasal respiratory epithelium, including the Clara cells, which then leads to lower $\mathrm{CC} 16$ production. In contrast, $\mathrm{CC} 16$ inhibits eosinophil chemoattractant and Th2 cytokine (IL-4, IL-5, IL-13) production (23). In other words, there is a dynamic balance between the local production of eotaxin-2 and CC16, which is disturbed in patients with chronic eosinophilic nasal inflammation (21).

Nasal corticosteroid administration increases CC16 levels in the nasal secretions of patients with PAR and in non-allergic and allergic patients with CRSwNP, but not in patients with SAR (15). In the nasal mucosa, glucocorticoids decrease the number of antigen-presenting cells, lymphocytes, mast cells, and eosinophils. Prolonged corticosteroid treatment suppresses the production of eosinophil chemoattractants and eosinophil infiltration in the nasal mucosa (24). This, in turn, lowers the release of toxic enzymes (ECP, MBP, and others) that damage the Clara cells. An interesting finding is the absence of any changes in CC16 levels in patients with SAR after nasal corticosteroid treatment. This phenomenon could be explained by strong seasonal variations in CC16 levels in the nasal secretions of SAR patients associated with specific seasonal allergens in the air.

\section{CC16 AND PROLONGED EXPOSURE TO AIR POLLUTANTS}

Current research has associated prolonged exposure to tobacco smoke (25), household heating with fossil fuels (wood in particular) (26), and chronic exposure to urban air pollutants (27) with decreases in CC16 levels in both serum and nasal secretions. Biagioni et al. (28) reported lower CC16 in nasal secretions and bronchoalveolar lavage in atopic individuals exposed to diesel exhaust. Although unknown, the mechanism leading to lower CC16 production could be similar to the one in cigarette smoking, which over time affects airway tissue repair. In an experimental study with rats, Xiao et al. (29) demonstrated that exposure to a mixture of air pollutants lowered CC16 mRNA expression initially, but also that it significantly increased after 30 days. They tried to explain this increase in CC16 with adaptation to prolonged unfavourable circumstances in which acute airway inflammation becomes chronic. However, CC16 can also increase during acute exposure. The case in point is the reaction of the airway epithelium to pollutant exposure in the swimming pools reported by Carbonnelle et al. (30). In trained swimmers, serum CC16 levels increased immediately after strenuous exercise, regardless of whether the pool water was treated with copper/silver or chlorine. They explained this acute increase in CC16 mucosal production with mechanical stress on the epithelial barrier caused hyperventilation during intense exercise.

\section{CONCLUSIONS}

CC16 is a strong anti-inflammatory protein that has an important role in the regulation of chronic eosinophilic inflammation of the nasal and paranasal sinus mucosa. Chronic eosinophilic upper airway inflammation, such as $\mathrm{AR}$ and CRSwNP, decreases CC16 production in the nasal mucosa. Intranasal corticosteroid administration directly suppresses local eosinophilic inflammation and stimulates local CC16 production. Similarly, most air pollutants suppress $\mathrm{CC} 16$ production in the nasal mucosa and bronchoalveolar epithelium.

CC16 can be a reliable biomarker of the efficacy of topical corticosteroid drugs in the treatment of chronic nasal inflammation and of the nasal mucosa recovery after the administration of topical corticosteroids. This protein may also be useful in estimating airway epithelium dysfunction after prolonged exposure to air pollutants.

\section{Conflicts of Interest}

None to declare.

\section{REFERENCES}

1. Galli SJ, Tsai M, Piliponsky AM. The development of allergic inflammation. Nature 2008;454:445-54. doi: 10.1038/ nature 07204

2. Oğhan F, Erdin I. Association among high altitude, allergic rhinitis, and bronchial hyperreactivity. ENT Updates 2017;7:47-52. doi: 10.2399/jmu.2017001006

3. Perić A, Vojvodić D, Vukomanović-Đurđević B, Baletić N. Eosinophilic inflammation in allergic rhinitis and nasal polyposis. Arh Hig Rada Toksikol 2011;62:341-8. doi: 10.2478/10004-1254-62-2011-2120

4. Henriquez OA, Beste KD, Hoddeson EK, Parkos CA, Nusrat A, Wise SK. House dust mite Der $\mathrm{p} 1$ effects on sininasal epithelial tight junction. Int Forum Allergy Rhinol 2013;3:630-5. doi: 10.1002/alr.21168

5. Wise SK, Laury AM, Katz EH, Den Beste KA, Parkos CA, Nusrat A. IL-4 and IL-13 compromise the sinonasal epithelial abrrier and perturb intercellular junction protein expression. Int Forum Allergy Rhinol 2014;4:361-70.

6. De Corso E, Baroni S, Romitelli F, Luca L, Di Nardo W, Passali GC, Paludetti G. Nasal lavage CCL24 levels correlate with eosinophil trafficking and symptoms in chronic sinonasal eosinophilic inflammation. Rhinology 2011;49:174-9. doi: 10.4193/Rhino10.133

7. Perić A, Sotirović J, Špadijer-Mirković C, Matković-Jožin $\mathrm{S}$, Perić AV, Vojvodić D. Nonselective chemokine levels in nasal secretions of patients with perennial non-allergic and allergic rhinitis. Int Forum Allergy Rhinol 2016;6:392-7. doi: 10.1002/alr.21684

8. Perić A, Baletić N, Sotirović J, Špadijer-Mirković C. Macrophage inflammatory protein-1 production and 
eosinophil infiltration in chronic rhinosinusitis with nasal polyps. Ann Otol Rhinol Laryngol 2015;124:266-72. doi: 10.1177/0003489414554944

9. Johansson S, Keen C, Ståhl A, Wennergren G, Benson M. Low levels of $\mathrm{CC} 16$ in nasal fluid of children with birch pollen-induced rhinitis. Allergy 2005;60:638-42. doi: 10.1111/j.1398-9995.2005.00775.x

10. Benson M, Jansson L, Adner M, Luts A, Uddman R, Cardell LO. Gene profiling reveals decreased expression of uteroglobin and other anti-inflammatory genes in nasal fluid cells from patients with intermittent allergic rhinitis. Clin Exp Allergy 2005;35:473-8. doi: 10.1111/j.1365-2222. 2005.02206.x

11. Benson M, Fransson M, Martinsson T, Naluai AT, Uddman $\mathrm{R}$, Cardell LO. Inverse relation between nasal Clara Cell Protein 16 levels and symptoms and signs of rhinitis in allergen-challenged patients with intermittent allergic rhinitis. Allergy 2007;62:178-83. doi: 10.1111/j.1398-9995. 2006.01264.x

12. Irander K, Palm JP, Borres MP, Ghafouri B. Clara cell protein in nasal lavage fluid and nasal nitric oxide - biomarkers with anti-inflammatory properties in allergic rhinitis. Clin $\mathrm{Mol}$ Allergy 2012;10:4. doi: 10.1186/1476-7961-10-4

13. Roth FD, Quintar AA, Leimgruber C, Garcia L, Uribe Echevarria EM, Torres AI. Restoration of the normal Clara cell phenotype after chronic allergic inflammation. Int J Exp Pathol 2013;94:399-411. doi: 10.1111/iep.12041

14. Špadijer-Mirković C, Perić A, Belić B, Vojvodić D. Clara cell protein 16 and eosinophil cationic protein production in chronically inflamed sinonasal mucosa. Int Forum Allergy Rhinol 2016;6:529-35. doi: 10.1002/alr.21710

15. Špadijer-Mirković C. Značaj određivanja medijatora inflamacije u nosnom sekretu za procenu intenziteta zapaljenja u alergijskom rinitisu [Importance of determination of inflammatory mediators in nasal secretions for estimation of the inflammation intensity in allergic rhinitis, in Serbian]. [PhD thesis]. Kragujevac: Faculty of Medical Sciences; 2016.

16. Liu Z, Lu X, Zhang X.H, Bochner BS, Long XB, Zhang F, Wang H, Cui YH. Clara cell 10-kDa protein expression in chronic rhinosinusitis and its cytokine-driven regulation in sinonasal mucosa. Allergy 2009;64:149-57. doi: 10.1111/j.1398-9995.2008.01847.x

17. Otto BA, Wenzel SE. The role of cytokines in chronic rhinosinusitis with nasal polyps. Curr Opin Otolaryngol Head Neck Surg 2008;16:270-4. doi: 10.1097/ MOO.0b013e3282fb2885

18. Hemelaers L, Henket M, Sele J, Burreau F, Louis R. Cysteinyl-leukotrienes contribute to sputum eosinophil chemotactic activity in asthmatics. Allergy 2006;61:136-9. doi: 10.1111/j.1398-9995.2006.00993.x
19. Kramer MF, Burow G, Pfrogner E, Rasp G. In vitro diagnosis of chronic nasal inflammation. Clin Exp Allergy 2004;34:1086-92. doi: 10.1111/j.1365-2222.2004.01989.x

20. Shin SH, Lee SH, Jeong HS, Kita H. The effect of nasal polyp epithelial cells on eosinophil activation. Laryngoscope 2003;113:1374-7. doi: 10.1097/00005537-200308000-00020

21. Perić A, Špadijer-Mirković C, Vukomanović-Đurđević B, Perić AV, Vojvodić D. Eosinophil chemokines and Clara cell protein 16 production in nasal mucosa of patients with persistent allergic rhinitis. Eurasian J Med 2017;49:178-82. doi: 10.5152/eurasianjmed.2017.17203

22. Shin SH, Park JY, Jeon CH, Choi JK, Lee SH. Quantitative analysis of eotaxin and RANTES messenger RNA in nasal polyps: association of tissue and nasal eosinophils. Laryngoscope 2000;110:1353-7. doi: 10.1097/00005537200008000-00025

23. Hung $\mathrm{CH}$, Chen LC, Zhang Z, Chowdhury B, Lee WL, Plunkett B, Chen CH, Myers AC, Huang SK. Regulation of Th2 responses by the pulmonary Clara cell secretory $10-\mathrm{kd}$ protein. J Allergy Clin Immun 2004;114:664-70. doi: 10.1016/j.jaci.2004.05.042

24. Mener DJ, Shargorodsky J, Varadhan R, Li SY. Topical intranasal corticosteroids and growth velocity in children: a meta-analysis. Int Forum Allergy Rhinol 2015;5:95-103. doi: 10.1002/alr.21430

25. Bernard AM, Roels HA, Buchet JP, Lauwerys RR. Serum clara cell protein: an indicator of bronchial cell dysfunction caused by tobacco smoking. Environ Res 1994;66:96-104. doi: 10.1006/enrs.1994.1047

26. Van Miert E, Sardella A, Nickmilder M, Bernard A. Respiratory effects associated with wood fuel use: a cross sectional biomarker study among adolescents. Pediatr Pulmonol 2012;47:358-66. doi: 10.1002/ppul.21554

27. Berthoin K, Broeckaert F, Robin M, Haufroid V, De Burbure C, Bernard A. Serum pneumoproteins and biomarkers of exposure to urban air pollution: a cross-sectional comparison of policeman and foresters. Biomarkers 2004;9:341-52. doi: 10.1080/13547500400018646

28. Biagioni BJ, Tam S, Chen YWR, Sin DD, Carlsten C. Effect of controlled human exposure to diesel exhaust and allergen on airway surfactant protein $\mathrm{D}$, myeloperoxidase and club (Clara) cell secretory protein 16. Clin Exp Allergy 2016;46:1206-13. doi: 10.1111/cea.12732

29. Xiao C, Li S, Zhou W, Shang D, Zhao S, Zhu X, Chen K, Wang R. The effect of air pollutants on the microecology of the respiratory tract of rats. Environ Toxicol Pharmacol 2013;36:588-94. doi: 10.1016/j.etap.2013.04.012

30. Carbonnelle S, Francaux M, Doyle I, Dumant X, de Barbure C, Morel G, Michel O, Bernard A. Changes in serum pneumoprotein caused by short-term exposures to nitrogen trichloride in indoor chlorinated swimming pools. Biomarkers 2002;7:464-78. doi: 10.1080/13547500210166612 


\section{Razine proteina 16 Clara stanica u nosnoj sluznici tijekom alergijskog rinitisa, kroničnog rinosinuitisa i izloženosti onečišćenom zraku}

Protein 16 Clara stanica (engl. Clara cell protein 16, krat. CC16) mali je protein kojega uglavnom stvaraju Clara stanice u respiratornom epitelu, koje nemaju cilije. Taj protein ima protuupalnu ulogu tijekom eozinofilnih upala gornjeg i donjeg dišnog puta. Niže koncentracije CC16 nađene su u nosnom sekretu i krvnoj plazmi pacijenata s kroničnim eozinofilnim upalnim bolestima, kao što su astma, alergijski rinitis i kronični rinosinuitis s nosnim polipima i bez njih, kao i u osoba koje su izložene onečišćenjima zraka. Primjena intranazalnih kortikosteroida blokira kroničnu eozinofilnu upalu nosne sluznice i stimulira lokalnu produkciju CC16. Protein CC16 može biti pouzdan biomarker ne samo poboljšanja funkcije nosne sluznice u pacijenata liječenih od perenijalnog alergijskog rinitisa i kroničnog rinosinuitisa nego i funkcionalnog oporavka nosne sluznice nakon terapije topikalnim glukokortikoidima.

KLJUČNE RIJEČI: glukokortikosteroidi; nosni polipi; posrednici upale 